\section{B A Institute of \\ YK Business Administration \\ TK Karachi \\ Leadership and Ideas for Tomorrow}

Article 14

Volume 4 Issue 1 January-June 2009

$1-1-2009$

\title{
A word about the IBA, About our authors, Back Matter
}

Tufail A. Qureshi

Institute of Business Administration, Karachi, Pakistan

Follow this and additional works at: https://ir.iba.edu.pk/businessreview

Part of the Business Commons

c) (i)

This work is licensed under a Creative Commons Attribution 4.0 International License.

\section{Recommended Citation}

Qureshi, T. A. (2009). A word about the IBA, About our authors, Back Matter. Business Review, 4(1), 207-219. Retrieved from https://doi.org/10.54784/1990-6587.1176

This article is brought to you by iRepository for open access under the Creative Commons Attribution 4.0 License and is available at https://ir.iba.edu.pk/businessreview/vol4/iss1/14. For more information, please contact irepository@iba.edu.pk. 


\title{
A WORD ABOUT THE IBA
}

\author{
IBA \\ YK \\ तर
}

\begin{abstract}
Our logo reflects "our resolve to meet the future challenges with integrated and multi - disciplinary knowledge and its creative application in a changing global environment."
\end{abstract}

\section{INTRODUCTION}

The IBA is the oldest business school outside North America. It was established in 1955 as a USAID financed project. Initially, the Wharton School of Finance, University of Pennsylvania, provided the technical support; later the University of Southern California got the contract to set up various facilities at the institute and several prominent American professors were assigned to IBA. A large number of Pakistani faculty members received advanced degrees from Wharton and University of California. In 1994, the Sindh Assembly elevated the Institute's status to that of a degree awarding institution.

Despite of a rapid increase in the number of business schools, the IBA has maintained its position as the premiere institution of higher learning in the field of management and business administration. The IBA sets the standards of educational and professional excellence. It seeks to advance and encourage new ideas and promote enduring values to guide the practice of management. Over the years, the IBA has built a reputation for producing graduates of unmatched professionalism and sound ethical and moral values. The IBA has an academic environment in which talented and outstanding young men and women are inspired to reach out to the farthest limits of their vision and capacities.

The IBA is proud of its 7,500+ accomplished alumni who are engaged in highly specialized and professional undertaking all over the world. Many of them hold demanding positions of administrative responsibilities in various fields of governance in Pakistan and abroad. We proudly celebrate their association with the IBA. 


\section{CORE VALUES}

We uphold:
- Merit
- Truth
- Integrity

- Creativity

- Discipline

- Tolerance

- Humility

as the creative dimensions of the "highest good" - summum bonum - of an ethically motivated academic life based on moral foundations.

\section{MISSION}

After completing its 50 glorious years of excellence, the IBA is geared up to achieve more milestones in the field of education, hence providing its commitment to continuous improvement.

At the IBA, our mission is to provide education and training for management leadership in business and public sector in Pakistan. We aspire to be the best business school in Asia and amongst the best in the world.

It is our cherished mission to establish links with renowned business schools in the world and with business and public sector organizations in Pakistan in order to introduce the current and contemporary business education, culture and work ethics for making Pakistan amongst the most competitive countries in the world.

\section{PHILOSOPHY}

The recurrent theme of the 53 years of IBA's existence is that business education should be relevant and looking to the future.

Our philosophy is rooted in the creative urge to strive continuously to improve upon all components of our system; culture, people and infrastructure; and to turn bright students with leadership potential into outstanding human beings and business professionals and leaders for tomorrow.

\section{MEETING THE CHALLENGES}

The IBA provides an enabling environment, conducive to scholarship and research. The faculty, staff, students and members of the industry work together to achieve learning goals. Students acquire knowledge and skills through constructive and distinctive processes that encourage them to develop understanding of business concepts and issues, think independently and to make rational choices. They are encouraged to take responsibility for their own learning, to become active participants and leaders and to apply their knowledge in real-world context. 
A fine blend of our academic environment, research culture and the highly qualified and devoted faculty at the IBA, moulds bright and intelligent students with leadership potential into high performing entrepreneurs and professional managers.

\section{THE GOALS AHEAD}

The IBA is set on a path of constant improvement, introducing changes in all critical fields of its undertaking. Its partnership with MICROSOFT has given a new dimension to the Center for Computer Studies, enabling students and faculty to remain abreast with the most advance technologies in software as well as hardware. It has entered into agreements with CBR to impart not only the quality education to its probationers but also to its senior members in the field of management in order to realize the government's policy to change the culture and the managerial practices of this sensitive department and to bring them to the accomplished level of modern-day needs and expectations.

\section{PROGRAMS OF STUDY AT THE IBA}

The IBA programs are designed to provide world-class professional training to managers and entrepreneurs for the business and industry in Pakistan. Students take part in a broad variety of activities ranging from volunteering for charity work and participating in athletic events to organizing conferences on a variety of business issues. A spirit of involvement is important because teamwork, leadership and being a responsible citizen are the foundations of the IBA experience.

Our programs have been growing steadily in keeping with the needs of the society and the competence of the Institute of Business Administration.

We offer courses in the fields of:

- Doctor of Philosophy - Ph.D. (MIS/ Information \& Communication Technologies (ICT)/ Computer Science \& Engineering (CSE)

- $\quad$ Master of Business Administration - MBA (Morning Program)

- Master of Business Administration - Management Information System MBA- MIS (Morning Program)

- $\quad$ MS (Economics)

- $\quad$ MS (Finance)

- $\quad$ Master of Business Administration - MBA (Evening Program)

- Master of Business Administration - Management Information Systems MBA- MIS (Evening Program)

- $\quad$ Postgraduate Diploma in Business Administration - PGD (Evening Program)

- $\quad$ Certificate Courses (Evening Program) 
- $\quad$ Visiting Students Program (Evening Program)

- $\quad$ Master of Business Administration - Tax Management (Morning Program)

- $\quad$ Bachelor of Business Administration - BBA (Morning Program)

- $\quad$ Bachelor of Business Administration - Management Information Systems BBA- MIS (Morning Program)

- $\quad$ Bachelor of Computer Studies - BCS (Morning Program)

- $\quad$ Preparatory Program for Rural Students (Talent Hunt)

- $\quad$ Business English Program

\section{CAREER OPPORTUNITIES}

In view of the increasing professionalism in management and growing competition in Pakistan, job opportunities for qualified and trained business administration graduate will continue to grow. Multinational firms and professionally managed Pakistani companies hire IBA graduates with confidence because of the high level of professionalism instilled in them during their course of study.

The Institute offers a flexible curriculum, a highly motivated student body and committed faculty that are willing to embrace and encourage new ideas and thought patterns. This provides the students with tools, values and confidence to be leaders in the corporate world of today and tomorrow.

The interaction of researchers, business and industry is necessary for new ideas to develop and be implemented. The Research Wing undertakes projects and assignments specific to a particular industry or an organization. A broad classification of these research projects pertains to areas related to Strategy, Growth, Economics, Organizational /HR Development, Marketing and Production Management.

\section{CENTER FOR EXECUTIVE EDUCATION}

The Center for Executive Education is a state-of-the-art learning and training resource center. It focuses on developing managers and providing opportunities for refining the skills needed to succeed in today's business environment.

The Center aims at helping organizations gain competitive advantage by developing their most important resource - their people. It is a nucleus for activities designed to enhance organizational effectiveness through training and developing working professionals in various disciplines and equipping them with the tools and knowledge to improve their managerial skills. The programs offered are designed to strengthen the participants' leadership skills with a focus on personal development, productivity improvement and strategic thinking. The Center specializes in executive education and 
management development activities through "open-enrolment courses, client-specific programs, consultancy and applied research.

\section{FEDERAL BOARD OF REVENUE (FBR) - CAPACITY BUILDING PROGRAM}

The IBA is providing training to the Tax and Customs officers of FBR in Karachi, Lahore and Islamabad. Up till now, 325 officers of grade 17 - 21 have been trained at the Center for Executive Education, Institute of Business Administration, Karachi. While under the FBR Capacity Building Program (Lahore) 2007, conducted at the Directorate of Training (Income Tax), Lahore from July 02-December 08, 2007, nearly 275 officers were trained

All the courses are designed by the faculty at IBA in consultation with FBR, which include Computer Skills, Communication and Presentation Skills, Management Skills, Leadership and Teambuilding Skills.

\section{MBA TAX MANAGEMENT PROGRAM FOR FBR}

This program is started in January 2005 at the Institute of Business Administration. Currently fourth batch of 35 students is enrolled under this program.

Around 149 FBR students have been trained under the said program up till now.

The MBA Tax Management Courses include Business \& Banking Laws, Financial Accounting, Human Resource Management, International Trade, Public Economics, Statistics \& Math for Business, Analysis of Financial Statements, Auditing, Business Policy, Change Management \& Business Process Reengineering, Financial Management, International Accounting Standard Financial Reporting in Pakistan, Management Accounting \& Control System

\section{CENTER FOR ENTREPRENEURIAL EXCELLENCE IN PAKISTAN}

United States of America has chosen the IBA for establishing a Center for Entrepreneurial Excellence in Pakistan under its broader Middle East and North African initiative. There will be a distinguished advisory panel titled as 'Blue Ribbon Panel', consisting of the Directors of Entrepreneurship Institutes at MIT, Babson, Harvard and Stanford. This panel will not only advise but also assist and support the new Pakistani Center. Dr. Peter Bearse, who is an international consulting economist and an expert in developing entrepreneurial center, is supervising the project. This Centre is important for boosting economic activity, employment and trade within the country and across the international markets. The centre will conduct research to identify training needs, to document how entrepreneurship is developed and run in the country, what are the opportunities and obstacles, rules and regulations for business and give proposal for policy and procedural improvements. 


\section{RESEARCH CENTER}

The IBA has established a Research Center at the City Campus. The purpose of the initiative is to play a key role in the development of industrial and financial sectors of Pakistan by providing useful research and evaluation guidance. The activities of the IBA's Research Center consist of both core and collaborative research to provide help to the federal and provincial governments, non-governmental organizations and the private sector.

The Center is a repository of the core research done by the IBA faculty, scholars and students. The research papers written are documented, archived and made available to other researchers and industry. The IBA faculty and students can access these research papers via the IBA internet.

\section{HIGH PROFILE FACULTY}

The IBA faculty comprises of teachers with high academic achievements as well as successful, practical business management experience. Most have advanced degrees in their field of specialization from foreign institutes of repute. The faculty members are well regarded for their insight and command over current issues facing business and industry. The faculty ensures that the system of education at the IBA is a unique blend of the best in classroom instruction, case studies, role-playing, business games, research and practical training in business organizations.

\section{HIGH ACHIEVING STUDENTS}

Our students win distinctions and praises from foreign and local dignitaries for their confident, reasoned discourse, organized team work and knowledge. The IBA student groups arrange dozens of seminars and conferences every year. As individual contestants our students have been successful in national and international competitions. Two of our students; Muniva Mahmood and Asim Ali Raza were chosen to go to Geneva in an international seminar. They joined 30 other business students from around the world. The IBA was the only school in the world which had the distinction of having two students accepted for the seminar. Last year Asnia Asim topped contestants from 109 countries to win the World Bank Essay Contest. The IBA team won Pakistan round of Microsoft India’s Imagine Cup 2006.

The IBA students are continuously giving evidence of being world class. During the past years, four students of IBA participated in the "Battle of Minds" organized by Pakistan Tobacco Company (PTC) wherein highly talented students of top Pakistani Universities competed against one another. The IBA students obtained the second 
https://ir.iba.edu.pk/businessreview/vol4/iss1/14

DOI: https://doi.org/10.54784/1990-6587.1176

Business Review - Volume 4 Number 1

January - June 2009

position for presenting a live research project in the Grand Slam. They were awarded trophies along with a cheque of Rs 200,000/-. In another competition namely "Novartis Biocamp", a team of two IBA students, competing with those of leading institutions of Pakistan, was sent to Tokyo, Japan in October.

The sure foundations of the state are laid in knowledge, not in ignorance; and every sneer at education, at culture, at book learning, which is the recorded wisdom of the experience of mankind, is the demagogue's sneer at intelligent liberty, inviting national degeneracy and ruin. $-G$. W. Curtis. 
https://ir.iba.edu.pk/businessreview/vol4/iss1/14

DOI: https://doi.org/10.54784/1990-6587.1176

Business Review - Volume 4 Number 1

January - June 2009

Both the Character Ethic and the Personality Ethic are examples of social paradigms. The word paradigm comes from the Greek. It was originally a scientific term, and is more commonly used today to mean a model, theory, perception, assumption, or frame of reference. In the more general sense, it's the way we "see" the world - not in terms of our visual sense of sight, but in terms of perceiving, understanding, interpreting. - Stephen R. Covey 


\title{
IBA \\ 当炎 \\ 光র
}

\section{BUSINESS REVIEW}

\author{
Research Journal \\ of \\ The Institute of Business Administration \\ Karachi, Pakistan
}

\begin{abstract}
About Our Authors
Ishrat Husain took over as the Dean and Director of the Institute of Business Administration (IBA), Karachi on March 12, 2008. Immediately before that he had been holding the office of Chairman, National Commission for Government Reforms (NCGR) in the Prime Minister Secretariat at Islamabad, with the status of the Federal Minister. In that capacity he completed a comprehensive report on the reorganization of the Government's structure, processes and human resource management policies.

Dr. Ishrat Husain became the Governor of Pakistan's Central Bank in December, 1999. During the next six years, he implemented a major program of restructuring of the Central Bank and steered the reforms of the banking sector, which are now recognized by the World Bank and IMF to be among the best in developing countries. In recognition of his meritorious services he was conferred the prestigious award of "Hilal-e-Imtiaz" by the President of Pakistan in 2003. The Banker Magazine of London declared him as the Central Bank Governor of the year for Asia in 2005. He received the Asian Banker Lifetime achievement award in 2006.
\end{abstract}

For over two decades, between 1979-1999, he served in various capacities at the World Bank in Washington DC. Among the positions he occupied at the Bank were Country Director for Central Asian Republics; Director, Poverty and Social Policy Department; Chief Economist, East Asia and Pacific Region; Chief Economist, Africa Region. Division Chief, Debt and International Finance and Resident Representative, Nigeria.

Dr. Ishrat Husain was selected to the elite Civil Service of Pakistan in 1964 and served in the field and also held mid-level policy making positions in Bangladesh (then East Pakistan) and in the Finance, Planning and Developing Departments in the Government of Sindh until 1979. 
He has maintained an active scholarly interest in development and globalization issues. He is the author of a dozen books, contributor of 15 chapters in edited books and more than 25 referred journal articles. Two of his books "Pakistan: The Economy of an elitist state" and "Economic Management in Pakistan: 19992002" published by the Oxford University Press are widely read in and outside Pakistan. He is regularly invited as a speaker, resource person, discussant, panelist or chairperson at International Conferences/ Seminars/ Workshops in different parts of the World held under the auspices of the World Bank, IMF, UN agencies, research institutions, think tanks. He has so far attended 100 such events.

Dr. Husain is Higher Education Commission's (HEC) Distinguished National Professor of Economics and Public Policy and is also the Chairman, HEC Social Sciences Council. He is currently serving on the Board of Trustees of the Aga Khan University, the Senate of Pakistan Institute of Development Economics, Board of Governors, National School of Public Policy and Mahbub-ul-Haq Centre for Human Development. He was a member of the Steering Committee on Higher Education appointed by the President of Pakistan in 2003.

Dr. Husain received his M.A. in Development Economics from Williams College and was at the top of his class and $\mathrm{Ph}$. D in Economics from Boston University receiving International Student Award for outstanding academic achievement. He is a graduate of the Executive Development Program jointly sponsored by Harvard, Stanford Universities and INSEAD.

Low Sui Pheng is a professor of construction technology and project management at the Department of Building, National University of Singapore. He received his PhD from University College London and is a Fellow of the Chartered Institute of Building. His research interests include international construction, productivity and quality.

Liu Jun Ying is Associate Professor in the Department of Construction Management at Tianjin University in China. She obtained her PhD from the University of Reading and is a Member of the Chartered Institute of Building.

Amos Cheong was formerly a Research Student in the Department of Building at the National University of Singapore. He obtained his BSc (Building) (Hons) degree from the National University of Singapore. He is presently working as a quantity surveyor with Rider Hunt Levett \& Bailey.

Muhammad Shakil Khan is Head of the Department of Management at Integral University, Lucknow, India. Dr. Shakil is also the Executive Editor of Integral Review, a Journal of Management published from the University. He is an MBA and 
has a Ph.D in Management from Magadh University, Bodh Gaya, India. He also has two Masters Degrees to his credit, one in Public Administration and the other in Human Rights and Duty Education, both from University of Madras, Chennai, India. He has been on various educational boards and is a resource person for teaching to the students of management. Dr. Shakil Enjoys a good research track record and has published a number of research papers both Nationally and Internationally. Dr. Shakil has an experience of about fifteen years in Research and Teaching in the areas of International Marketing and International Business.

Ahmed Audu Maiyaki graduated from Bayero University, Kano, Nigeria with a B.Sc Business Administration. He got a postgraduate degree from University of Ilorin, Nigeria. Presently he is teaching in the department of Business Administration, Bayero University, Kano, Nigeria. He is an associate member of the Nigerian Institute of Management. His research interest is in Services Marketing.

Khurshid M. Kiani Khurshid Kiani holds an M.A. in Economics from the University of Punjab, Lahore, Pakistan an M.A. in Economics from the Kansas State University, Manhattan Kansas, and a Ph.D. in Economics from Kansas State University, Manhattan Kansas USA, in 2003. Kiani worked as Assistant Professor in the Department of Economics at Wilfrid Laurier University, Waterloo, Ontario, Canada, Assistant Economic Adviser, and Research Officer to the Government of Pakistan, Ministry of Finance, Islamabad, and Assistant Director, National Tariff Commission, Ministry of Commerce, Islamabad Pakistan. At present he is a faculty member in the Department of Economics at the University of the West Indies at their Mona Campus at Kingston Jamaica and teaches econometrics at all level and sequence of financial economics courses at graduate level.

His research interests center on conventional statistical modeling that encompasses stable distributions, conditional heteroskedasticity, and long memory, and unconventional statistical predictive modeling, using techniques such as neural networks, genetic algorithms, and entropy in an out-of-sample predictive framework. His research work appears in Oxford Bulletin of Economics and Statistics, Computational Economics, Applied Financial Economics, Quarterly Review of Economics and Finance, Applied Economics and International Development, Transition Studies Review, Pakistan Development Review, International Journal of Applied Economics and Business Review.

Mian Sajid Nazir holds a MS Finance COMSATS Institute of IT. He has a master degree in Business Administration from the same university. He has four years of experience of research and teaching in the areas of Credit, Investment and Portfolio Analysis, Financial Management, Business Finance, and Strategic FM. Prior to his joining at COMSATS, he has worked at the Department of Management Sciences GCU Faisalabad as Project Manager. Currently, he is working as Lecturer in the 
Department of Management Sciences at Lahore campus of COMSATS Institute of Information Technology. He has presented four research papers in international conferences at Dhaka, Singapore, USA, and Lahore. He also has three journal publications on his credit. His areas of research interests include Financial Management, Working Capital Management, Portfolio Investment, Corporate Strategies, and FDI.

Talat Afza holds a Ph.D. in International Trade and Finance from Wayne State University, Detroit USA. She has a master degree in Economics from the same university. She also holds Master of Business Administration degree with major in Finance from B.Z. University, Multan Pakistan. She has extensive experience of research and teaching in the areas of International Finance, Investment and Portfolio Analysis, Financial Management, Economics and Money \& Banking. She has taught at various prestigious universities including University of Michigan Dearborn (USA), Wayne State University, Detroit (USA), B.Z. University (Multan), University of Lahore (Lahore) and Virtual University of Pakistan. Currently, she is working as Dean of the faculty of Business Administration at COMSATS Institute of Information Technology. She has more than twenty publications to her credit. Her areas of research interests include International Trade and Finance, Money \& Banking and Portfolio Management. She has rendered consulting and advisory services to various organizations such as Habib Bank Limited, Population Welfare Department, Konya Industries (Pvt.) Limited, Pakistan Institute of Entrepreneurship Training, Ministry of Industry and Population, Government of Pakistan. She is a member of Punjab Vocational Training Council, Government of Punjab and Pakistan Institute of Development Economists.

Muhammad Ayub Siddiqui did his BSc (Hons) and MSc in Economics from IIIE in 1989 and M.Phil (Economics) from Quaid-i-Azam University Islamabad in 1992. He has published research papers in the journals of international repute, Journals. His work has also been published in the International Journal of Economic Perspectives.

Khair-uz-Zaman Professor in Economic, MS, Ph.D and Post Doctorate from Bradford University UK. He is a Higher Education Commission (HEC) recognized Supervisor in Management Sciences, Economics Department Gomal University D. I. Khan.

Muhammad Imran Khan Lecturer in Management Sciences, Ph.D Scholar in Management Sciences, MBA (IT) from IBMS, NWFP Agriculture University Peshawar.Management Sciences Department, Qurtuba University of Science and Information Technology D.I.Khan. 
https://ir.iba.edu.pk/businessreview/vol4/iss1/14

DOI: https://doi.org/10.54784/1990-6587.1176

Business Review - Volume 4 Number 1

January - June 2009 
https://ir.iba.\&du.pk/businessreview/vol4/iss1/14

DOI: https://doi.org/10.54784/1990-6587.1176

\section{Business Review}

\section{IA}

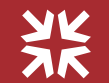

Contents of Volume 1 Number 1, July - December 2006

Articles, Discussions, Fact File and Book Reviews

\section{Articles}

Articles Impact Analysis-Applying the modified combined mode

of Kirkpatrick's and Phillips Training Evaluation to measure the

Training Impact: Toshio Fujita

Socioeconomic Status as Predictor of Marital Adjustment in

Working Women: Zeenat Ismail, Kausar Ansari

Why do Firms Manage their Earnings? : Zeeshan Ahmed

Corporate Social Responsibility: Akbar Abdul Ali

Random Walk Tests for KSE-100 Index: Evidence and Implications:

Abdul Rashid

Knowledge Entrepreneurship: A new Paradigm for Organizational

Performance: S.M. Taha

Mechanisms Underlying the Phenomenon of Cluster Formation in

the Textile/ Apparel Industry in Pakistan: Khadija Bari ..

Language and the Structuring of the Intellect: Towards the Realization

of the Total Man: D.U. Opata

\section{Discussions}

Discussions Wavelet based SARIMA models for Forecasting Natural Gas Demand:

S.M. Aqil Burney, Major Afzal Saleemi, Syed Akhter Raza

Perceptions and Attitudes of University-Going Young Adult Males

about Metro sexuality - An Exploratory study: Farheen Faiyaz, Carissa

P.S. D' souza, Nasir Ahmed Syed

Influence of Foreign Media on Fashion in Young Adults in Pakistan:

Arif Hasan, Shaza Bari

The Influence of Children on Family Purchase Decisions:

A Phenomenological Approach: Usman Majeed, Nadia S. Banoori.

\section{Fact File}

Fact File Have we missed the rally?: Talib Haider

Book Review Barbara D. Metcalf, Islamic Contestations. Essays on Muslims in 
https://ir.iba.edu.pk/businessreview/vol4/iss1/14

DOI: https://doi.org/10.54784/1990-6587.1176

\section{Business Review}

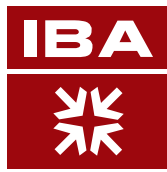

Contents of Volume 2 Number 1, January - June 2007

Motif, Articles, Research, Discussions and Book Reviews

\section{Motif}

Japan Pakistan Relations: Challenges and Opportunities

from Japan's New Economy. Seiji Kojima

Japanese Ambassador Extraordinary and Plenipotentiary .............................................. 06

\section{Articles}

On Predictability in South Asian Stock Markets: Khurshid M. Kiani

Authentic Leadership Style and its Implications in Project Management:

Shamas-ur-Rehman Toor, George Ofori, Faisal Manzoor Arain

Contemporary Attempts at Overcoming Decadence and Revitalizing

Qur'anic Thought : Muhammad Ata al-sid

Investigating Technicist - managerialism in the Values Endorsed in

MBA Programmes : Sara Khan

The Scale of Operation, Profitability based Productivity and Capacity

Utilization in Seaports, The Case Study based on the Colombo Seaport

in Sri Lanka, 1980-2005 : Sarath W.S.B Dasanayaka

Financial Reforms and Common Stochastic Trends in International

Stock Prices: A Case Study of Pakistan: Mohammad Nishat, Ch. Muhammad Irfan

\section{Research}

Towards a Vision 2030: Direction of Industrial Development in Pakistan

A Summary of the Study conducted by: Japan International Cooperation

Agency and International Development Center of Japan

\section{Discussions}

The Analysis of Non-Financial Qualitative Factors for Corporate Value

Creation: Syed Umar Farooq

Corruption Improves Efficiency: An Erroneous Belief: Naved Ahmed

Innovation Studies in Different Countries: Future Research Agenda

for Pakistan: Syed Awais Ahmed Tipu

The Case for Including Study of Arts in Management Development

Curricula: Humayun S. Ansari

Diversification in Banking sector with Special References of Finance:

Yaseen Ahmed Meenai

\section{Book Review}

Aman U. Sayed: Management Accounting for Financial Services

Jim Collins: Good to Great, Harper Business, Muhammad Ahsan Siddique ... 
https://ir.iba.edu.pk/businessreview/vol4/iss1/14

DOI: https://doi.org/10.54784/1990-6587.1176

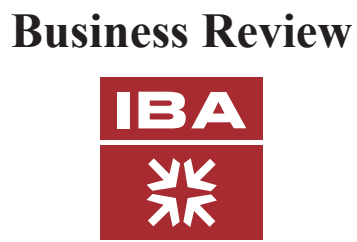

Contents of Volume 2 Number 2, July - December 2007 Articles, Discussions, Research, Book Reviews and Reportage

\section{Articles}

Building National Digital Infrastructure -A Case Study of Semiconductor Complex Ltd:

Deepak Kapur

Analyzing Construction - related Market Trends in APEC Countries using GIS:

Low Sui Pheng, Benny Raphael, Faisal Manzoor Arain, Susan Soh

Family Functioning as A Risk Factor in The Development of Juvenile Delinquency:

Zeenat Ismail, Zaeema Riaz

The Causal Link between Stock Returns and Trading Volume: Some Evidence from an

Emerging Market: Abdul Rashid

The Drivers and Barriers to Customer Value Creation: Issues and Perspectives in the

Marble Sector SMEs of North-West Frontier Province, Pakistan: Muhammad Nouman

Conflicting Paradigm: Alternative Islamic Approaches to Business Ethics Discourses:

Javed A. Ansari, S. Zeeshan Arshad

\section{Discussions}

Entrepreneurial Opportunities and Market Analysis of the Information Technology and

Software Development Sector of Pakistan: Toshio Fujita, Hassan Tajuddin

Branding Pakistan For The Future: Umair Naeem

Research

\section{Book Review}

Business Ethics in Pakistan.

\section{Reportage}

$4^{\text {th }}$ International Research Symposium (SCRI) in conjunction with the International Built and 
https://ir.iba.edu.pk/businessreview/vol4/iss1/14

DOI: https://doi.org/10.54784/1990-6587Bţsiness Review

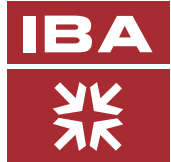

\section{Contents of Volume 3 Number 1, January - June 2008 Articles, Discussions, Case Studies}

\section{Articles}

Is Good will Impairment Loss Meaningful Information?

Orapin Duangploy, Khursheed Omer, Justo Manrique and Margaret Shelton

Institution of Bureaucracy and The Conflict in South Asia: Huma Baqai ...........................223

Effects of Free Trade Agreements (FTAs) on Construction Firms in Singapore:

Low Sui Pheng and June S.Y. Khoo.

Economic Reforms and Total Factor Productivity Growth in Pakistan: An Empirical Analysis:

Muhammad Sabir and Qazi Masood Ahmed

SMEs in Globalized World: A Brief Note on Basic Profiles of Pakistan's Small and Medium Scale

Enterprises and Possible Research Directions: Sarath W.S.B. Dasanayaka

On Nonlinearities in KSE 100 Index Stock Return: Khurshid M. Kiani

\section{Discussions}

Training within Oil and Gas-Based Industries in the State of Qatar: Hend A. Jolo

Managing Knowledge Worker: Shandana Shuaib

Gradient-Based Edge Detection on a Hexagonal Structure: Xiangjian, Tom Hintz,

Qiang Wu and Wenjing Jia

The Role of Governance and Its Influence on Quality Enhancing Mechanism in Higher Education: Syed Naeem Ahmed

Spiritual Basis of Worldly Success: Dr.iur.Menno Aden

\section{Case Studies}

Pilot Study of 8 SMEs in Pakistan: Ejaz Ahmed Mian 


\section{O N T E N T S}

Editorial Perspective

\section{Articles}

Post - Globalization Power Sector Management in India:

J.G. Valan Arasu, A.D.N. Bajpai, Shubhada Pandey

Capitalist Subjectivity, Capitalist Governance and the 'Anti-Globalisation' Movement:

Javed A. Ansari, Syed Zeeshan Arshad, Ali Muhammad Rizvi

Leveraging on Knowledge Management Approach for Effective Risk Management in Building Projects: Faisal Manzoor Arain

The Implementation of Trademark Law in Small and Medium Size Enterprises (SME)

Business Activities in Indonesia: Alexander Y Agung Nugroho, Sih Yuliana

Wahyuningtyas.

Brand Loyalty, Store Loyalty and Demographic Variables: Relational Study:

Zeenat Ismail.

\section{Discussions}

Consolidation in Indian Banking Industry - Need of the Hour:

Syed Ahsan Jamil, Bimal Jaiswal, Namita Nigam

Converged Service of Data, Video and Voice -Readiness of Pakistani Market:

Syed Irfan Nabi, Danish Akbar, Karim Chagani, Adnan Anwar Khan,

Anwar ul Haq.

The Influence of Culture on Advertising Effectiveness in Pakistan and Australia: A CrossCultural Study: Faiz Muhammad Shaikh.

\section{Case Studies}

Pilot Study of 8 SMEs in Pakistan: Ejaz Ahmed Mian

\section{News and Views}

$5^{\text {th }}$ European Symposium on Gender and ICT 2009

A Word About the IBA

About our Authors

Note for Contributors

Contents of Vol. 1, No. 1, Vol. 2, No. 1, Vol. 2, No. 2 and Vol. 3, No. 1 